\title{
Settlement and Agricultural Practices of Bemba Shifting Cultivators in Northern Zambia from Multi-temporal LANDSAT TM Images
}

\author{
Shuichi Oyama*
}

\begin{abstract}
In the miombo woodland of Northern Zambia, the Bemba have practiced a unique shifting cultivation called Citemene. Men climb up trees and pollard the branches to open fields for agriculture. Tree branches are collected and taken to a garden from surrounding tree-cutting areas before they are set on fire in October. Newly opened Citemene fields could be recognized as white circles with black centers on LANDSAT TM images. This study examines the settlement and agricultural pattern of 8 households by applying multi-temporal LANDSAT TM images from 1984, 1989, 1992 and 1994. In 1984, the population was concentrated along the road, cultivating hybrid maize, which was introduced by the Zambian Government. Around 10 households set up seasonal dwellings during the dry season to open Citemene, but most of the villagers remained resident at the roadside. They simultaneously opened Citemene and cultivated maize although some households became dependent on maize cultivation. In 1987, the fertilizer supply became unfavorable for farmers in remote areas and they began to open Citemene actively. In 1989, approximately 30 households began to set up seasonal dwellings along the seasonal marsh, but they returned to the settlement and cultivated maize near the road during the rainy season. In 1990 a bridge was destroyed and that made it impossible for vehicles to go by the shortest way from the township to the village. The fertilizer supply was interrupted and it became difficult for them to continue the maize cultivation. Citemene became more important for maintaining subsistence, as an alternative to maize cultivation. The villagers abandoned the settlements along the road and shifted their base to the site of the seasonal dwellings. In 1994, woodland suitable for Citemene was exhausted around the new settlement and the villagers set up seasonal dwellings along the river. They prepared land for Citemene from a base of seasonal dwellings during the dry season, but they stayed at the settlement along the seasonal marsh during the rainy season. In 1997, they shifted their settlement again to seasonal dwelling area along the river. There was plenty of water at the river although they had had trouble getting water before. Not only mature woodland but also water availability is important in selecting a place for seasonal dwellings and settlement. Where the distance between the settlement and newly opened Citemene increased to 3 to $5 \mathrm{~km}$, they set up seasonal dwellings near the seasonal marsh or rivers. When the distance became longer than 3 to $5 \mathrm{~km}$ from seasonal dwellings to new fields, they left the settlement for seasonal dwelling area. The villagers shifted their base with their relatives at 3 to 4years' minimum interval. These periods accord with the crop rotation of Citemene. They could furnish themselves with staple and subsidiary foods from the fields around the seasonal dwellings at least 3 to $4 y$ years after setting up seasonal dwellings and they shifted settlement to the seasonal dwelling area. After the fertilizer supply became unstable in the mid-1980's, they started actively seeking mature woodland with plenty of water. Spatial mobility was important for the Bemba to maintain their shifting cultivation and subsistence.
\end{abstract}

Keyword: Citemene shifting cultivation, forest utilization, Bemba, Zambia, remote sensing monitoring

\section{INTRODUCTION}

Savanna and woodlands in tropical areas are undergoing rapid changes in vegetation structure, productivity and composition, because of intensive human over-
* Department of Geography, Graduate School of Science, Tokyo Metropolitan University, Minami-Osawa 1-1 Hachi-oji 192-0397, Tokyo, Japan. 
utilization caused by over-stocking, fuel wood collection and shorter periods between crops (LEwIS and BERRY, 1988; WEBSTER and WILSON, 1989). Simultaneously deforestation affects the people's way of life, subsistence, production and so on (Mortimore, 1998; Maruyama and Morioka, 1998).

Remote sensing is a useful method for analyzing the vegetation changes and sustainability of shifting cultivation in relation to natural vegetation. Applications of remote sensing in Africa have been numerous, such as cases in Republic of Congo and Central African Republic (Defries et al., 1997), in tropical forests of south-western Ghana (Foody et al., 1996) and in the dry zone of Mali, Guinea and Senegal (Lambin and Strahler, 1994). These studies calculated NDVI by applying data from NOAA AVHRR and LANDSAT MSS, and examined the relationships among vegetation cover, climate condition and NDVI.

The vegetation in Northern Zambia is regarded as Miombo woodland (TRApNeLl, 1957; LAwTon, 1964). YANG and PRINCE (2000) analyzed the vegetation changes of 1972 and 1989 in South Luangwa National Park by classifying Landsat MSS. OYAMA $(1996,1998)$ conducted research of forest ecology in Miombo woodland and classified Landsat TM image from 1992 under four categories on the basis of defining three fallow periods of Citemene an indigenous shifting cultivation practiced by the Bemba people living in Northern Zambia. Three fallow periods are minimum fallow period, optimum fallow period and ecological fallow period. Sprague and Oyama (1999) examined the Citemene fields situation over an extensive area of $1,129 \mathrm{~km}^{2}$ of miombo woodland obtained from LANDSAT TM images, and calculated the cycle time in order to compare it with the three kinds of fallow periods. We also calculated the distance between fields and road for 1984 and 1992. The average distance from road in 1992 was longer than in 1984.

These previous studies examined extensive land cov- erage, but it is difficult to explain human activities from satellite images. This paper analyzed the spatial distribution of shifting cultivation fields and settlement patterns of Bemba people, focusing on 8 households within an area of approximately $80 \mathrm{~km}^{2}$. One of the major aims was to indicate the forest utilization and spatial planning of Bemba shifting cultivators, by applying a combination of ground information and multi-temporal satellite images.

\section{STUDY AREA}

The research was conducted in Mpika District in Northern Province, Republic of Zambia (Fig. 1). This paper focuses on Mulonga village, $60 \mathrm{~km}$ westward from Mpika town, the center of Mpika District. Mulonga village (S11.41.30, E030.57.00) is about $30 \mathrm{~km}$ west of Mulenga Kapuli village (Fig. 2) where Kakeya and Sugryama have researched ecological anthropology since 1983 (KAKEYA and Sugryama, 1985, 1987; Sugryama, 1987). The study period in Mpika District is total 26 months from October 1993 to August 1999.

Mulonga village was established in 1943 under Chief

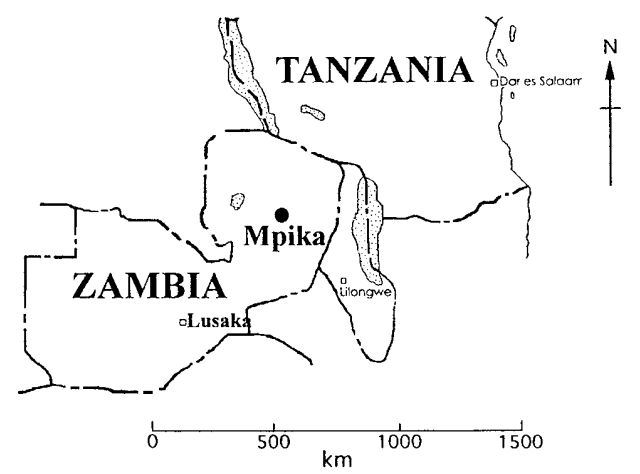

Fig. 1 The location of Mpika Township, Northern Zambia

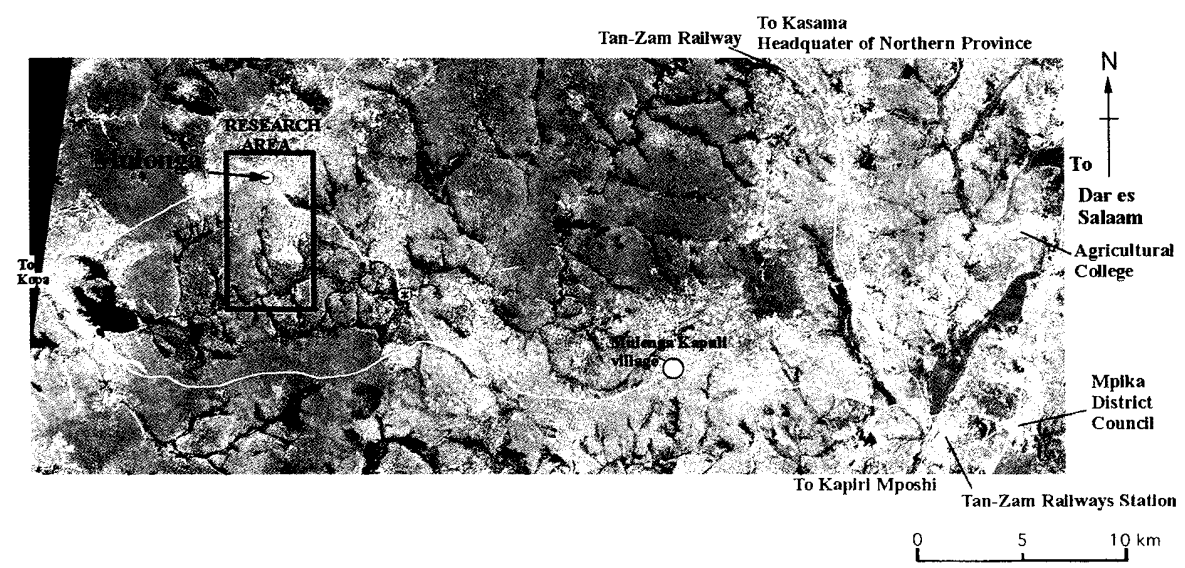

Fig. 2 Research area around Mulonga village, Mpika District, Northern Province, Republic of Zambia (LANDSAT TM; Band5/4/3, date 8/25/1984) 
Luchembe, local chief of the Bemba Kingdom. In 1997, 80 households, 414 people were living in the village. There were a primary school, four churches and residences of agricultural extension workers in the Mulonga village center (Fig. 3).

Climate and Environment

The research area belongs to the Northern Plateau region of miombo woodland with elevation between 1,200 and $1,400 \mathrm{~m}$ above sea level. Along the rivers meandering in the woodland, there were seasonal marshes called "dambo". Rivers and dambo are important water

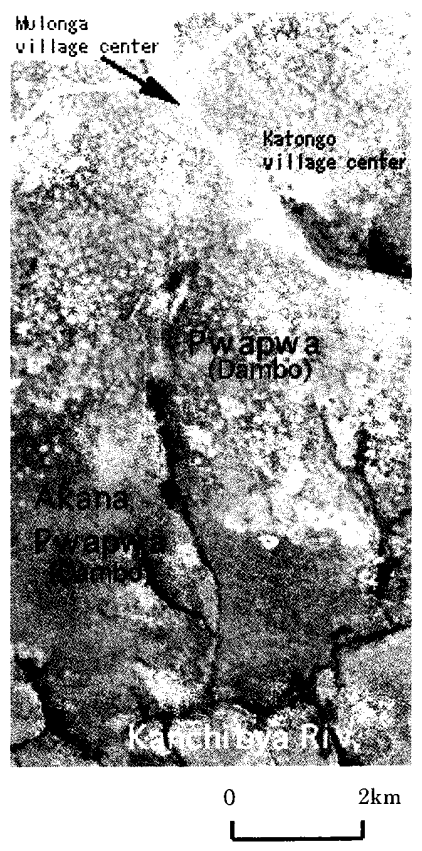

Fig. 3 Dambo, rivers and newly opened Citemene fields around Mulonga village resources for the Bemba, because there is no rainfall in the dry season from May to October. In the research area, Kanchibya River runs from west to east and a dambo called Pwapwa flows into Kanchibya River (Fig. 3). Akana Pwapwa, which means small Pwapwa, is a tributary of Pwapwa.

The average annual rainfall is $1,130 \mathrm{~mm}$ in Mpika Town Center and the rainy season extends from November to April (Survey Department of Zambian Government, 1986). The dry season is divided into two sub-seasons; cold-dry season from May to the beginning of August and hot-dry season from the middle of August to October (Fig. 4). The soil of this region is classified as Orthic Ferralsols (FAO, 1974) with sandy topsoil.

The vegetation around the study area is Miombo woodland, which is dominated by Brachystegia, Julbernardia and Isoberlinia, which belong to Caesalpinioidea (TRAPNELL, 1957; Lawton, 1964; Oyama, 1996). These deciduous trees compose a 10 to $15 \mathrm{~m}$ high canopy, while the grassesHyparrhenia sp. and Loudetia sp. cover the ground. "Miombo" is derived from the local generic term. These woodlands cover large areas of south-central Africa where annual rainfall varies from 600 to $1,400 \mathrm{~mm}$, with annual mean temperature ranging between 18 and $24^{\circ} \mathrm{C}$.

\section{Agricultural Systems; Citemene Shifting Cultivation}

Bemba people practice Citemene shifting cultivation in the Miombo woodland. At the beginning of April, when the rainy season comes to the end, men go to the place selected for Citemene in advance and cut trees in order to prepare for opening fields. This work continues until the middle of September. There are two ways of cutting treescutting down trees (ukutema panshi) and lopping branches (ukusaila). When lopping branches, men take off their footwear and climb up the trees (Fig. 5). The trees, which are selected for lopping, are larger than $15 \mathrm{~cm}$ in $\mathrm{DBH}$.

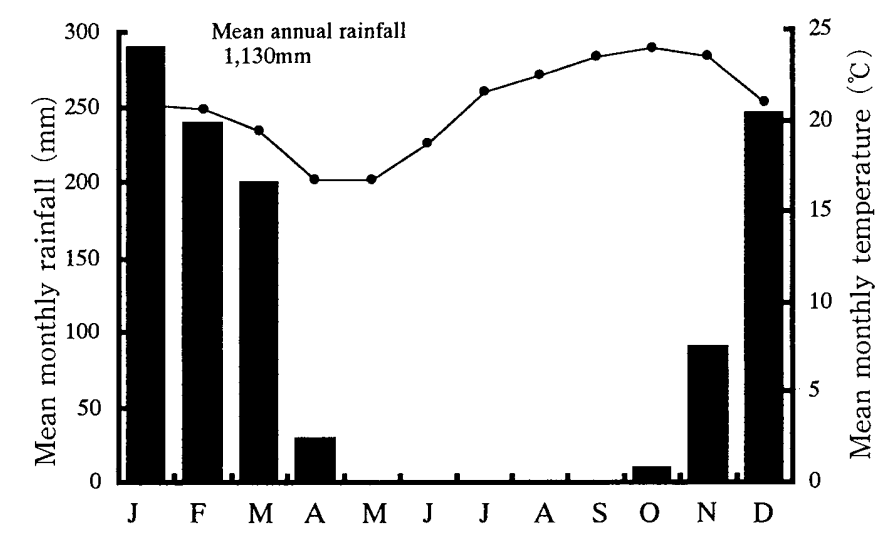

Fig. 4 Mean temperature and rainfall in Mpika Town Center (Survey Department of Zambian Government, 1986) 
They lop the branches by axes without cutting down stems. Some men said, "It is a true Bemba man that can climb up and lop branches without troubles and fear". In cutting down trees, they select trees, which are smaller than $15 \mathrm{~cm}$ in $\mathrm{DBH}$.

After the cut branches and leaves are dried on the ground for several weeks, women carry them into the future garden area in the center of the cleared area of woodland, and pile them up to $70 \mathrm{~cm}$ high. These future fields with piled materials are called "Citemene" in Bemba language and the term is also used as the name of the agricultural system. In the mid-October, immediately before the rainy season, they set fire to the dried wood and establish the fields, which are called Ubukula. The average area of a Citemene garden is 0.4ha. Newly opened Citemene or burnt Ubukula fields were recognizable on Landsat TM images. In most cases, new Citemene appeared as white circles with black centers (Fig. 3).

Citemene have the same cropping system in general, finger millet for the first year, groundnuts for the second year, cassava for the third year and beans occasionally for the fourth year.

After the fire, family members plant cassava cuttings and women sow seeds of tomato, pumpkin and edible gourd at the edge of the Ubukula field. Judging the rainy condi-

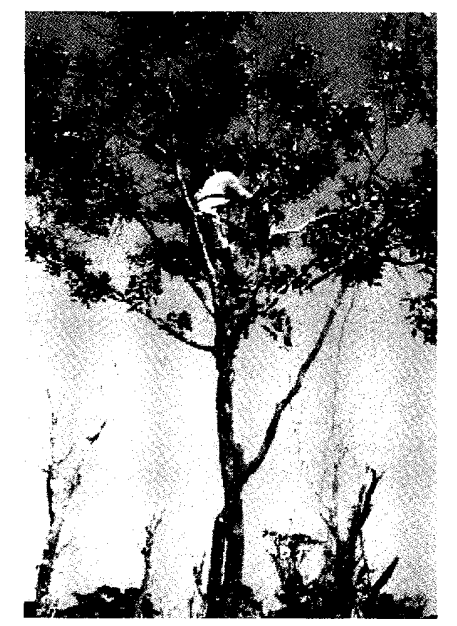

Fig. 5 Men climb up trees and pollard the branches

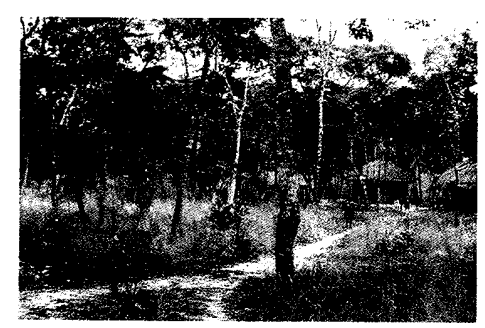

Fig. 6 Settlement (nganda) of Bemba people tion, they broadcast finger millet around Christmas. In the following May, women start to harvest finger millet. The fields after they finish harvesting are called "Cifwani". Finger millet, important staple food and other crops are harvested during May to July. There is a hunger season for the Bemba people from February to April immediately before the next harvest season.

In the mid-October, when the dry season ends, they set fire to the dried finger millet stems and sow seeds of groundnuts and cowpea in Cifwani from late November to early December. Then, they harvest the crops during the following May to June.

In the third year's fields, they harvest cassava with their occasional demands. After that, they sometimes make the ridges for growing common beans, but in many cases they abandon the fields. The abandoned fields are called "Cifumbule".

They set up seasonal dwellings called mitanda during the dry season. All family members stay there from May to September and the adults go to new Citemene fields to prepare land. After finishing agricultural works during the dry season, they return to the settlement, called nganda. Settlement dwellings have clay walls with a straw-thatched roof (Fig. 6), whereas they make seasonal dwellings (mitanda) out of straw only (Fig. 7).

As a basis for assessing the ecological sustainability of Citemene shifting cultivation, CHidumayo (1987) suggested that fallow periods of 25 years are necessary after Citemene fields are opened. LAwTON (1978) demonstrated 25-30 years, and BOALER and ScIwALE (1966) estimated 50 years. Oyama (1996) distinguished the minimum fallow period, optimum fallow period and ecological fallow period. Minimum fallow period is the shortest term, which allows the production of staple food (finger millet), but causes environment degradation. Minimum fallow period is calculated as 2 years in the tree-cutting area and 26 years in the garden area, after they open the previous fields. Optimum fallow periods, which may supply enough

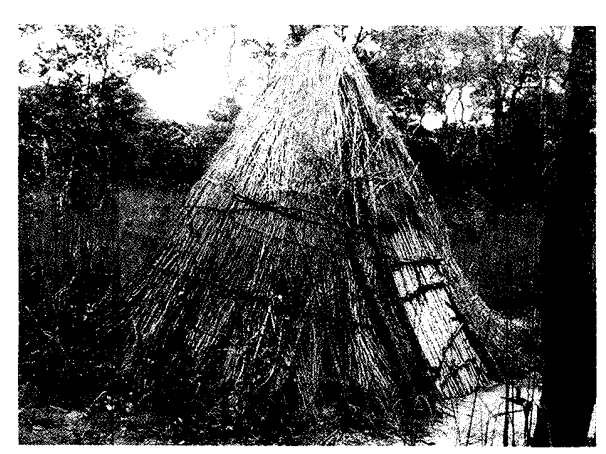

Fig. 7 Seasonal dwellings (mitanda). The Bemba people stay at seasonal dwellings during the dry season and work for land preparation. 


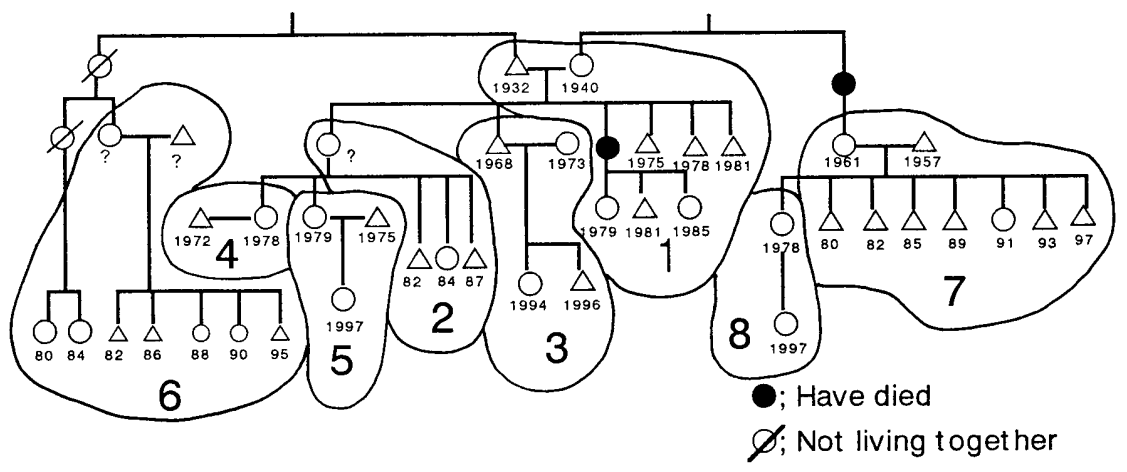

Fig. 8 Kinship relation of 8 households in Jan. 1998.

biomass for finger millet production and make ecologically sustainable utilization of miombo woodland possible, were estimated to be 16 years for the tree-cutting area and 35 to 40 years for the garden area. The ecological fallow period that allows forests to recover more fully is 30 years in the tree-cutting area and more than 50 years in the garden area.

\section{METHODS AND PROCEDURES}

The author acquired data for the miombo woodland and Citemene positions from four, cloudless LANDSAT TM satellite images (path 170, row 68), dated 25th August 1984, 19th November 1989, 16th September 1992 and 22nd September 1994. LANDSAT TM satellite images were selected to obtain uniform data set and image resolution.

Agricultural works such as cutting trees and piling branches were carried out mainly during August-October, and the works were nearly completed in November. The positions of Citemene fields black centers with white circles were captured by the satellite image. Erdas (Ver. 7.5 and Ver. 8.4) was applied to analyze the images and the images were georeferenced by Zambian Government Maps in the UTM projection (zone 36, spheroid: Clark 1880).

The author conducted a ground survey in Mulonga village from October 1997 to February 1998. This paper analyzes the settlement pattern and agricultural practices of 8 households with 41 people in Mulonga village ${ }^{1)}$ by applying both ground survey and remote sensing methods.

These 8 households had kinship relations (Fig. 8),

\footnotetext{
1) The total population of Mulonga village was 80 households with 414 people.

2) LANDSAT images for the research area were not frequently taken and suitable period for analysis was limited. During the rainy season there is much cloud and the positions of newly opened Citemene could be identified on the images only for three months- from end of August to middle of November.
}

which are matrilineal. Core members included a couple of Household No. 1. The husband of No. 1 was born in 1932 and his wife was born in 1940. A female of No. 8 divorced her husband in 1998 after bride service was finished and they became independent from No. 7. After divorcing, she was dependent on her parents (Household No. 7). The author also examined the settlement and cultivation patterns of some households who opened Citemene near Pwapwa dambo and Akana Pwapwa dambo, in addition to the 8 households.

The places of settlement, seasonal dwellings and Citemene cultivation were measured by GPS (Magellan Meridian XL-3000) on the site and were plotted on Landsat images after interviews with villagers. Color-coding of the Landsat images in 1984, 1992 and 1994 were Band 5 as red, Band 4 as Green and Band 3 as Blue. For the 1989 image Band 7, Band 5 and Band 2 were combined for clear demonstration, because there is a possibility that Band 4 and Band 3 have defects in their data set. The positions of some Citemene fields in 1992 could not be identified from the image, because the 1992 image did not capture all of the study area. The position of two settlement sites, one seasonal dwelling and twelve Citemene fields of 8 households in 1996 and 1997 were measured by the GPS and were overlaid on the 1994 LANDSAT image. This aimed to clarify the relationship between settlement, cultivation pattern and natural vegetation given the limitation of LANDSAT image data ${ }^{2}$.

The periods as well as the reasons for setting up seasonal dwellings or shifting settlement were investigated in the interviews. The author measured the area of Citemene on the ground and could match a cultivator's name with each field on the image. The area of Citemene was classified by "Man Value" of the household members, which was set according to RICHARDS and WIDDOwSON's standard (RICHARDS and WIDDOwson, 1937) in order to analyze their degree of food self-sufficiency. Man Value was defined as 1.0 for each male of 14 years old and over, 0.8 for each female of 14 years and over, 0.7 for each child

\section{J. For. Plann. 6:65-74(2001)}


between 6 and 14 years old and 0.4 for each infant, except for breast-fed infants.

\section{RESULTS}

According to the male of Household No. 1, most of the villagers in Mulonga village lived along the road from 1977 to 1990 . There are primary school and churches along the road and the population was concentrated in the village center. The Zambian Government supplied chemical fertilizers and $F_{1}$ hybrid maize seed in order to promote modern agriculture development, even in remote areas like Mulonga village. The Government also set up an agricultural marketing board and bought maize at favorable prices from the farmers. The male said that they lived along the road mainly in order to obtain chemical fertilizer and hybrid seed. In 1984, they cultivated the maize fields near the village center and also went to Citemene from the settlement in order to open and maintain the fields (Fig. 9). When the supply of agricultural input materials was suitable in the 1980's, some of them practiced modern agriculture entirely and stopped opening traditional Citemene.

The male of Household No. 1 returned to Mulonga village in 1975 after finishing construction of the Tan-Zam railway, which was financed by Chinese grants. He and his family lived beside the road from 1975 to 1980 . During that period, they actively cultivated maize fields and simultaneously maintained Citemene fields near Pwapwa dambo. In 1981, he decided to set up mitanda seasonal dwellings along Pwapwa dambo and to stay there with his wife and children during the dry season, because suitable woodland for opening Citemene was diminishing near the village center. During the dry season, the male cut trees and his wife piled branches into the future cultivation area after harvesting finger millet. The villagers in Mulonga village, including Household No. 1, opened Citemene fields and cultivated maize at the same time. There were only 10 households who set up seasonal dwellings (Fig. 9), and the others stayed along the road all the year round, because they did not regard Citemene as important for the staple food production.

Up to 1984 wildlife inhabited woodland in the Kanchibya River area and the males went hunting during around a one-week stay in the bush. About one week's hunting, they could obtain 10-20 head of common duiker (Sylvicapra grimmia), waterbuck (Kobus ellipsiprymnus) and so on. Such hunting with several nights stay in the bush is called ulutunti in the Bemba language.

In 1987, the supply and marketing of fertilizers became unstable and unfavorable for farmers in remote areas. Most of the villagers started to open Citemene actively while continuing the unstable maize cultivation near the settlement. In the 1989 satellite image (Fig. 10), reflectance values of the pixels along the road are high and this was associated with maize fields, which were spreading near the villages. The maize fields had a small amount of vegetation cover during the dry season. Approximately 30 households began to set up seasonal dwellings along Pwapwa dambo in 1989, but they returned to the settlement and cultivated maize near the road during rainy season.

In 1990, a bridge over Kanchibya River (the place marked $*$ on Fig. 1) was destroyed and that made it impossible for the vehicles to go by the shortest way from Mpika Township to Mulonga village. From 1990 the supply of fertilizers to the village was disrupted and it became difficult for most of the villagers to continue the maize cultivation. Some of them obtained chemical fertilizers privately from acquaintances living in other villages, or bought fertilizers in the local market of Mpika town. The availability of fertilizers was limited and Citemene became an important agriculture for their subsistence.

In 1990, Household No. 1 abandoned nganda near the village center and shifted its settlement to seasonal dwellings place along Pwapwa dambo. They began to stay at Pwapwa all the year round in 1990. From 1990 to 1993, they opened Citemene fields within $3 \mathrm{~km}$ of the new settlement. The satellite image in 1992 proved the distance from the village center to new Citemene fields along Pwapwa to be longer than $8 \mathrm{~km}$ (Fig. 11). These new Citemene fields were opened by the villagers living along Pwapwa.

There were several households setting up seasonal dwellings along dambo, $4 \mathrm{~km}$ east of the village center, but they still lived in the settlement near the village center during the rainy season. Around 1990 the wildlife was decreasing and the villagers carried out ulutunti-hunting over several days less frequently.

In 1994 woodland suitable for opening Citemene was exhausted around the new settlement, and Household No. 1 set up seasonal dwellings with their relatives again at the confluence of Pwapwa dambo and Kanchibya Rivers. There was plenty of virgin woodland historically there was no human impact from the shifting cultivation on the southern side of Kanchibya River (Fig. 12). The forest consists of Brachystegia spiciformis, B. utilis, B. longifolia and Julbernardia paniculata. A bridge of logs was made to cross the river for Citemene cultivation. Household No. 1 opened Citemene from the seasonal dwellings during dry season and stayed at the settlement along Pwapwa dambo during the rainy season. In the rainy season, they harvested available crops such as pumpkin, cassava and beans from the settlement.

In 1997 Household No. 1 shifted their settlement again to the place of seasonal dwellings, because there were fewer forests near the old settlement and they had finished harvesting most of crops at the fields around the old settlement. Household No. 1 and their relatives left the settlement of Pwapwa dambo and carried their baggage, tools and crops on the head or by the bicycle for a few days. 


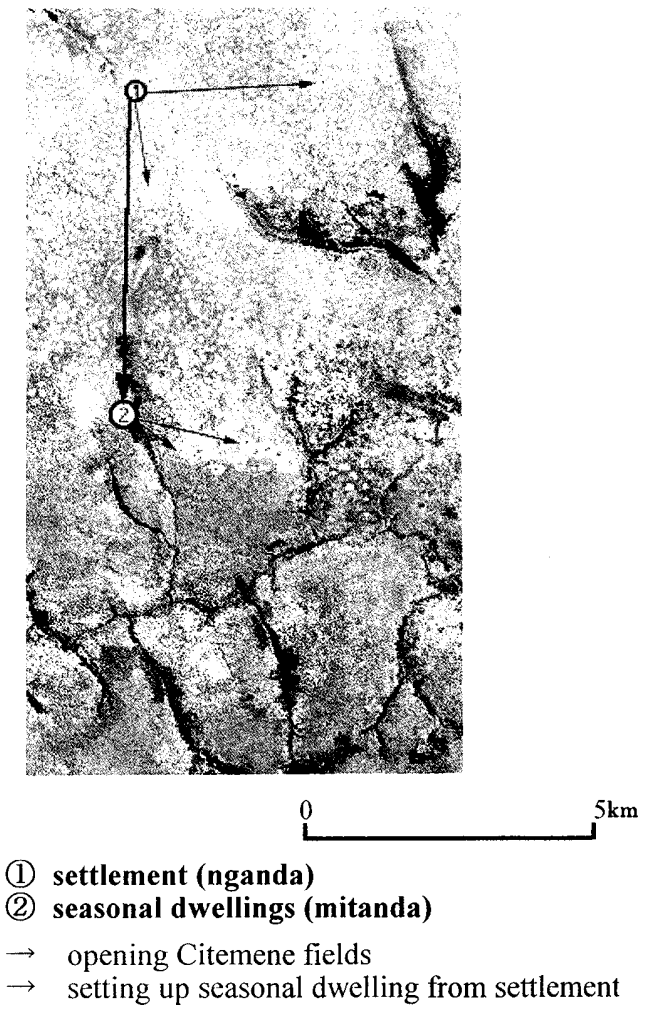

Fig. 9 August 1984. LANDSAT TM (Band 5/4/3)

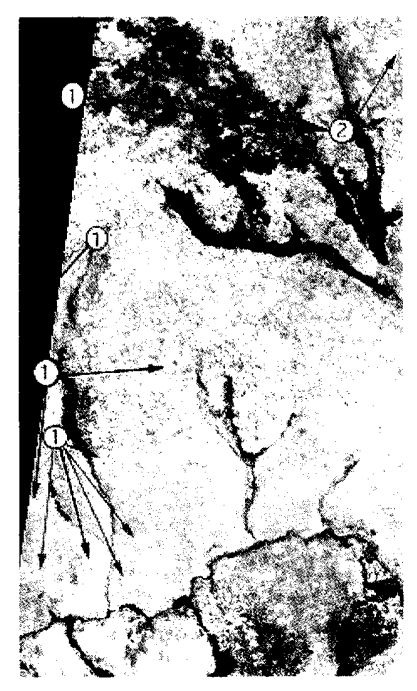

Fig. 11 September 1992. LANDSAT TM (Band 5/4/3)

From August 1997, they started living at Kanchibya River. There was plenty of water available to them at Kanchibya River all the year round, although they had trouble getting water in Pwapwa dambo during the dry season. The locations of 8 households' Citemene fields in 1996 and 1997 were on the other side of Kanchibya River from the new settlement (Fig. 13). The villagers improved the bridge

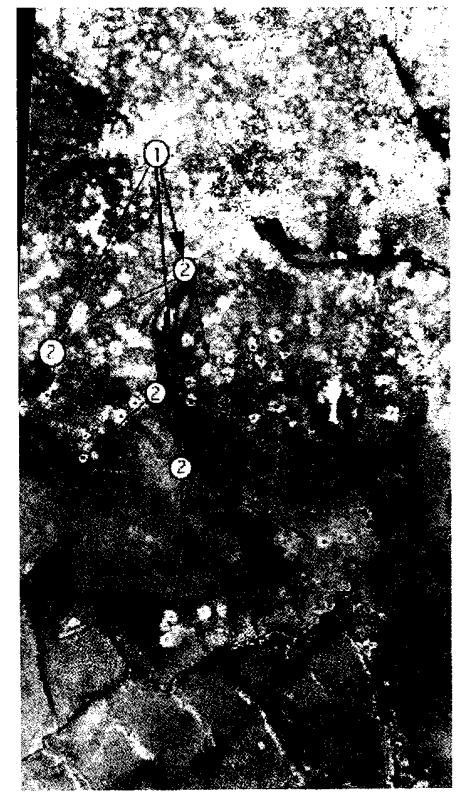

Fig. 10 November 1989. LANDSAT TM (Band 7/5/2)

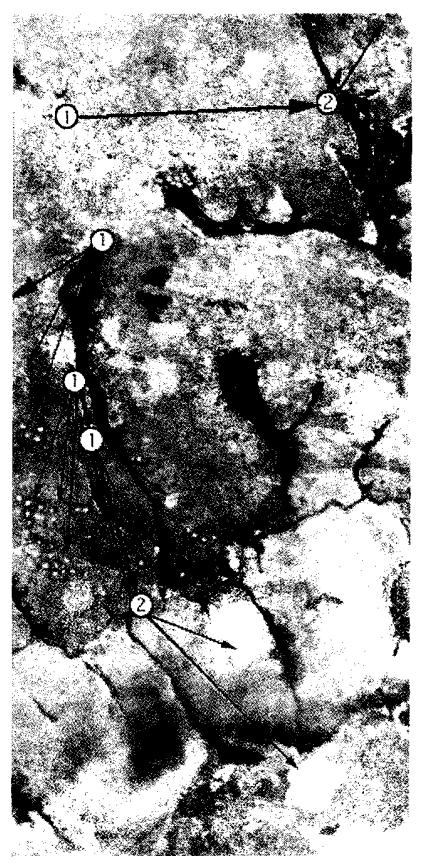

Fig. 12 September 1994. LANDSAT TM (Band 5/4/3)

and crossed the rivers in order to open and maintain their fields. A young male (husband of Household No. 4) who was born in 1972 (Fig. 8) took his close younger brother-inlaw (husband of Household No. 5) and set up seasonal dwellings with their wives in 1996. They prepared for Citemene fields just in 1996 and stopped setting up seasonal dwellings in 1997. The two males thought that it was not 


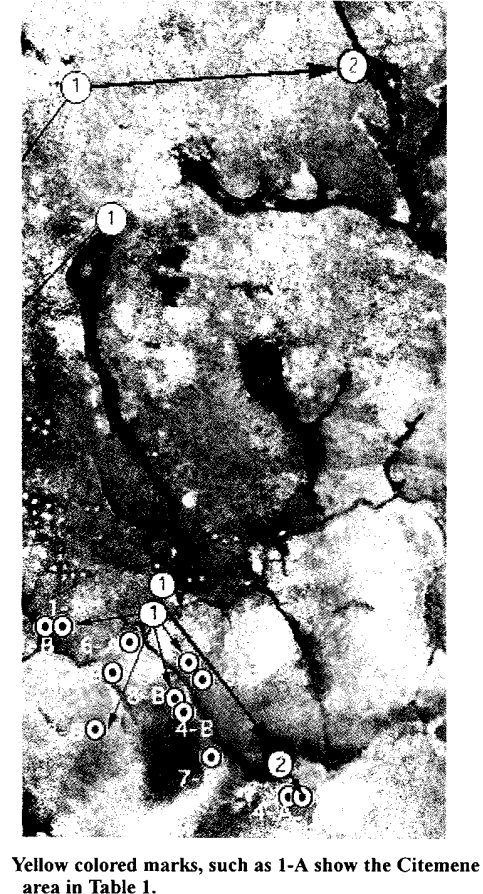

Fig. 13 The location of Citemene fields opened in 1996 and 1997 on LANDSAT image, September 1994.

good for them to stay at seasonal dwellings by themselves because they did not have direct kinship within the 8 households and they were unwilling to disagree with the relatives.

The Citemene area of the 8 households varied from 0.12 to 0.68 ha (Table 1 ). Citemene cultivation is based on household labor, and the number of household members is an important factor for determining the scale of Citemene fields. A male considers his own health and the food situation of his own and neighboring households, and finally he decides the appropriate tree-cutting area. Households who had opened small Citemene in the previous year, like Households No. 3, 5 and 6, had expanded their area of newly opened Citemene in order to maintain their subsistence. However, after they had opened larger Citemene than subsistence level, they reduced the size next year, like Household No. 2 and 7.

The area of Citemene area has also relation with the tree-cutting (ukusaila; Fig. 5) skills and desire of the males. Especially in the virgin forest of the research area, the trees have straight stems and it is difficult for males to climb and pollard branches.

KaKEYA and Sugryama (1985) indicated that households whose Citemene sizes were larger than 0.09ha per one Man-Value can maintain subsistence by shifting cultivation. According to that standard, Households No. 3, 4 and 5 could achieve food self-sufficiency although it seemed to be difficult for the other households to maintain subsistence by Citemene. The younger generations such as Households No. 3, 4 and 5, shared staple food, such as finger millet and cassava with their relatives (Households No. 1, 2, 6 and 7) especially in the hunger season.

\section{DISCUSSIONS}

Around 1980, the population of Mulonga village concentrated along the road and they cultivated maize. After the supply of fertilizers became unstable, the people became less dependent on maize cultivation and began to open Citemene more actively. In order to continue Citemene cultivation, it was necessary to shift their fields. When the distance between the settlement and new fields increased to 3 to $5 \mathrm{~km}$, they set up seasonal dwellings near dambo or rivers where water was available. They returned

Table 1 The area of Citemene and Man Value of 8 households in 1996 and 1997 agricultural seasons.

\begin{tabular}{cccccc}
\hline $\begin{array}{c}\text { Household } \\
\text { No. }\end{array}$ & $\begin{array}{c}\text { Man Value } \\
{[\mathrm{A}]}\end{array}$ & $\begin{array}{c}\text { Citemene area } \\
1996 ;(\text { ha })\end{array}$ & $\begin{array}{c}\text { Citemene area } \\
1997 ;(\text { ha })\end{array}$ & $\begin{array}{c}\text { average area } \\
{[\mathrm{B}]}\end{array}$ & $\begin{array}{c}\text { area per one Man Value } \\
{[\mathrm{B}] /[\mathrm{A}]}\end{array}$ \\
\hline 1 & 7.3 & $0.465^{1-\mathrm{A}}$ & $0.466^{1-\mathrm{B}}$ & 0.466 & 0.064 \\
2 & 3.3 & 0.399 & $0.120^{2-\mathrm{B}}$ & 0.260 & 0.078 \\
3 & 2.6 & 0.153 & $0.372^{3-\mathrm{B}}$ & 0.263 & 0.101 \\
4 & 1.8 & $0.381^{4-\mathrm{A}}$ & $0.398^{4-\mathrm{B}}$ & 0.390 & 0.216 \\
5 & 1.8 & $0.149^{5-\mathrm{A}}$ & $0.485^{5-\mathrm{B}}$ & 0.317 & 0.078 \\
6 & 6.9 & $0.401^{6-\mathrm{A}}$ & $0.681^{6-\mathrm{B}}$ & 0.541 & 0.053 \\
7 & 6.9 & 0.400 & $0.109^{7-\mathrm{B}}$ & 0.412 & -176 \\
8 & 0.8 & $\mathrm{X}$ & $0.314^{8-\mathrm{B}}$ & & 0.084 \\
\hline
\end{tabular}

Note 1) The marks such as 1-A show the Citemene positions in Fig. 13, although no marks means that the Citemene fields were not existing within the image.

2 ) Household No. 8 did not open Citemene in 1997, before they got married. After their one year marriage life, she divorced with her husband and was completely depended on her parents (Household No. 7) from 1998. 


\begin{tabular}{|c|c|c|c|}
\hline along the road & Pwapwa dambo & Kanchibya River & dambo \\
\hline $\begin{array}{c}\text { settling along the road } \\
\text { (maize cultivation) } \\
{[1977-1980]}\end{array}$ & $\begin{array}{l}\text { setting up seasonal } \\
\text { dwellings } \\
\text { [198 }{ }^{-1989]} \\
\text { shifting settlement } \\
\text { opening Citemene } \\
\text { from settlement } \\
\text { [1991-1993] }\end{array}$ & $\begin{array}{c}\text { setting up seasonal } \\
\text { dwellings } \\
{\left[1994{ }^{1996]}\right.} \\
\Downarrow \\
\text { shifting settlement } \\
\text { [1997] }\end{array}$ & $\begin{array}{l}\text {...setting up seasonal } \\
\text { dwellings[1997] } \\
\text { (only household } \\
\text { No. } 4 \text { \& 5) }\end{array}$ \\
\hline
\end{tabular}

Fig. 14 Settlement pattern of Household No. 1 and their relatives.

to their settlement from the seasonal dwellings after finishing agricultural works at the end of September. During the rainy season, they went to the fields directly from their settlement, not through seasonal dwellings. The agricultural works in the rainy season were harvesting pumpkin at the first year fields, cassava at the third year fields and beans at the fourth year fields, and weeding at the second year fields of groundnuts. Again when the distance became longer than 3 to $5 \mathrm{~km}$ from seasonal dwellings to newly opened fields, they left the settlement for a new site the place of seasonal dwellings and carried all their baggage, including agricultural tools, food, blanket and so on. They shifted their base to the place of seasonal dwellings.

The periods from setting up seasonal dwellings to shifting settlement were at least 3 to 4 years (Fig. 14) the same as the crop rotations of Citemene fields. They finished harvesting most of the crops in the field in these periods. This means that for 3 to 4 years after setting up seasonal dwellings they could furnish themselves with staple foods and subsidiary materials from the fields around the seasonal dwellings. It was not necessary for them to stay at the settlement and they shifted to the place of seasonal dwellings. According to a previous report in the 1930's (RICHARDS, 1939), the Citemene system had a two or three year crop rotation system without cassava because cassava was introduced by British administrators during 1930's. The mobility of people in the 1990's might be lower than in the 1930's, because of the longer period of crop rotation in Citemene. The 8 households were not willing to open more extensive fields than required food selfsufficiency. They carried out "under-production", as KaKEYA and SugrYama (1985) termed their mode of production.

In selecting a place for their seasonal dwellings, they attached importance not only to mature woodland, which allowed the opening of Citemene but also to the availability of water, as Richards (1939) stated. They continued to shift their settlements and seasonal dwellings along dambo or rivers. By setting up seasonal dwellings and shifting their settlement, the sustainability of shifting cultivation could be maintained.

\section{CONCLUSIONS}

The settlement pattern of 8 households, an object of this study, is to set seasonal dwellings or to shift their settlements at 3 to 4 years' minimum interval after they had left the roadside village. They moved for 3 to $5 \mathrm{~km}$ between 1990 and 1997. Under the modern condition, the average distance of resettlement could be calculated for approximately 400 to $700 \mathrm{~m}$ per one year.

The Bemba people have practiced Citemene at least since 19th century, although Citemene and mitanda were banned by the Administrator from 1906 (MEEBELO, 1971). Mitanda were not permitted, and only rough shelters (sakwe) were allowed in which the male head of household could sleep, but not his wife and children, during times of cutting trees, gathering branches and so on (Moore and VAUGHAN, 1994). The British colonial government encouraged the Bemba to live in villages along roads in order to achieve the social cohesion necessary for efficient administration.

In Mulonga village, the population was concentrated along the road between the 1970's and mid-1980's for the main purpose of gaining access to cash crop cultivation and fertilizers, which were supported by Government subsidy. After maize cultivation became difficult in the mid-1980's, the villagers start seeking mature woodland with plenty of water and the spatial mobility was important for promoting sustainability of Citemene shifting cultivation. They utilize miombo woodland more "widely and sparsely" in order to maintain their livelihood. This mode of agricultural practices avoids forest degradation and overutilization of woodland, but the area of virgin forest will be decreasing. 


\section{ACKNOWLEDGMENT}

This study was supported by the Japan Ministry of Education, Science and Culture Grant-in-Aid for International Scientific Research (\#08041059; representative Professor M. KAKEYA and \#11691186; representative Professor S. Araki), Matsushita International Foundation (\# 97-003) and the Japan Science Society Grant (\# 12-023).

\section{LITERATURE CITED}

Boaler, S. B. and Sciwale, K. C. (1966): Ecology of a miombo site, Lupa North Forest Reserve, Tanzania III. Effects on the vegetation of local cultivation practices. Journal of Ecology 54: 577-587

Chidumayo, E. N., (1987): A shifting cultivation land use system under population pressure in Zambia. Agroforestry systems 5: 12-25

Defries, R., HANSEN M., and MARC, E., (1997): Subpixel forest cover in Central Africa from multisensor, multitemporal data. Remote Sens. Environ. 60: 228-246

FAO, (1974): Soil map of the world. UNESCO, Paris

Foody, G. M., Boyd, D. S. and Curran, P. J., (1996): Relations between tropical forest biophysical properties and data acquired in AVHRR channels 1-5. Int. J. Remote Sensing 17 (7): 1341-1355

KaKeyA, M. and Sugiyama, Y., (1985): Citemene, finger millet and Bemba culture: A socio-ecological study of slash-and-burn cultivation in Northern Zambia. African Study Monographs, Suppl. 4: 1-24

Kakeya, M. and Sugryama, Y., (1987): Agricultural changes and its mechanism in the Bemba villages of Northeastern Zambia. African Study Monographs, Suppl. 6: 1-13

Lambin, E. F. and Strahler, A. H., (1994): Change vector analysis in multitemporal space: A tool to detect and categorize land-cover change processes using high temporal-resolution satellite data. Remote Sens. Environ. 48: 231-244

LAwton, R. M., (1964): The ecology of the Marquesia acuminata (GILG) R. E. FR. evergreen forests and the related chipya vegetation types of north eastern Rhodesia. Journal of Ecology 52: 467-479

Lawton, R. M., (1978): Study of the dynamic ecology of Zambian vegetation. Journal of Ecology 66: 175-198
Lewis, L. A. and Berry, L., (1988): African environments and resources. Allen and Unwin, Boston, $404 \mathrm{pp}$

Maruyama, M. and Morioka, N. (1998): The impact of deforestation in Brazilian Amazonia - the indigenous people of Rondonia State. Journal of For. Plan. 4(2): 71-75

Meebilo, H. S., (1971): Reaction to colonialism- A prelude to the politics of Independent in Northern Zambia 1893-1939. Manchester University Press, New York, 304 pp

Moore, H. L. and Vaughan, M., (1994): Cutting down trees. James Currey, London, 278 pp

Mortimore, M., (1998): Roots in the African Dust-Sustaining the drylands. Cambridge University Press, Cambridge, 219 pp

Oyama, S., (1996): Regeneration process of the Miombo woodland at abandoned field of Citemene shifting cultivation in Northern Zambia. African Study Monographs 17 (3): 101-116

OYamA, S., (1998): Environmental utilization and its change of Bemba people in miombo woodland, northern Zambia. Tropics 7(3/4): 287-303 (in Japanese)

Richards, A. I., (1939): Land, labour and diet in Northern Rhodesia. Oxford University Press, London, 424 pp

Richards, A. I. and Widdowson, E., (1937): A dietary study in Northern Rhodesia. Africa 9: 166-196

Sprague, S. D. and Oyama, S., (1999): Density and Distribution of Citemene Fields in a Miombo Woodland Environment in Zambia, Environmental Management 24 (2): 273-280

Sugryama, Y., (1987): Maintaining a life of subsistence in the Bemba village of Northern Zambia. African Study Monographs, Suppl. 6: 15-31

Survey Department of Zambian Government, (1986): Vegetation and Climate Map. Government Printer, Lusaka

Trapnell, C. G., (1957): The Soil, Vegetation and Agriculture of North Eastern Rhodesia. Government Printer, Lusaka

Webster, C. C. and Wilson, P. N., (1989): Agriculture in the Tropics. Longman Scientific and Technological, Essex, $640 \mathrm{pp}$

$Y_{A N G}$, J. and PRINCE, S. D., (2000): Remote sensing of savanna vegetation changes in Eastern Zambia 1972-1989. Int. J. Remote Sensing 21 (2): 301-322

(Received 28 April 2000) (Accepted 18 October 2000) 